\title{
Perbedaan Hasil Belajar Matematika Kelas 4 SD dalam Pembelajaran Menggunakan Model Discovery Learning dan Problem Based Learning
}

\author{
Fitria Intan Pramudi Wardani ${ }^{1}$, Mawardi $^{2}$, Suhandi Astuti ${ }^{3}$ \\ ${ }^{1,2,3}$ Pendidikan Guru Sekolah Dasar, Universitas Kristen Satya Wacana \\ 1292014187@student.uksw.edu, ${ }^{2}$ mawardi@staff.uksw.edu, ${ }^{3}$ suhandi.astuti70@gmail.com
}

\section{INFO ARTIKEL}

Riwayat Artikel:

Diterima: 25-02-2018

Disetujui: 22-03-2018

\section{Kata Kunci:}

Discovery Learning

Problem Based Learning

Hasil Belajar

Matematika

\begin{abstract}
ABSTRAK
Abstrak: Penelitian eksperimen ini bertujuan untuk menguji ada tidaknya perbedaan secara signifikan hasil belajar matematika kelas 4 SD dalam pembelajaran menggunakan model discovery learning dan problem based learning di Gugus Slamet Riyadi Ampel-Boyolali. Jenis penelitian ini adalah penelitian eksperimen semu (quasi experimental) dengan desain Nonequivalent Control Group Design. Populasi dalam penelitian ini adalah seluruh siswa kelas 4 SD Gugus Slamet Riyadi Ampel-Boyolali. Sampel penelitian yang diambil yaitu siswa kelas 4 SDN 1 Kaligentong (SD inti), siswa kelas 4 SDN 2 Urutsewu dan siswa kelas 4 SDN 3 Urutsewu. Instrumen pengumpulan data menggunakan lembar observasi dan soal tes. Teknik analisis data menggunakan Uji-T. Berdasarkan hasil penelitian serta analisis data, disimpulkan bahwa hasil belajar menggunakan model discovery learning lebih tinggi secara signifikan dibanding model pembelajaran problem based learning. Hal tersebut ditunjukkan dari hasil uji thitung sebesar -2,282 dengan diperoleh signifikasi sebesar 0,026 lebh kecil dari $\alpha=0,05$ $(0,026<0,05)$, karena nilai signifikasi (2-tailed) pada independent sample t test lebih kecil dari 0,05 maka Ho ditolak dan Ha diterima. Oleh karena model discovery learning lebih efektif maka guru disarankan mengunakan model tersebut guna meningkatkan hasil belajar siswa.
\end{abstract}

\begin{abstract}
This study aims to examine the significant differences of mathematics learning result at $4^{\text {th }}$ grade elementary school in Gugus Slamet Riyadi Ampel-Boyolali which used discovery learning and problem based learning method. This study is quasi experimental with Nonequivalent Control Group Design. The data collection of this study is allt $4^{\text {th }}$ grade elementary school students in Gugus Slamet Riyadi AmpelBoyolali, but the sample used is $4^{\text {th }}$ grade students at SDN 2 Urutsewu and SDN 3 Urutsewu. The method of collecting data used is observation and questionnaires. The technique of analyzing data uses T-test method. Based on the result of the study, it is concluded that learning result using discovery learning method has significant result than problem based learning method. The result can be seen that the result of $T_{\text {hitung }}$ has 2,282 with 0,026 singnification which means it is less than $\alpha=0,05(0,026<0,05)$. The value of Sig.2-tailed at independent sample t-test is less than 0,05, so that $H_{0}$ is rejected and $H_{a}$ is accepted. The conclusion of this study is that discovery learning more effective and teachers are suggested to use that method in teaching-learning activity so that the students' learning result increase.
\end{abstract}

\section{A. LATAR BELAKANG}

Pendidikan menduduki posisi yang sangat penting bagi keberlangsungan hidup manusia, pendidikan juga memiliki fungsi yang telah ditetapkan sebagai acuhan untuk tercapaianya tujuan pendidikan yang bermutu. Fungsi pendidikan tersebut telah tercantum dalam Undang-Undang Nomor 20 Tahun 2003 tentang Sistem Pendidikan Nasional yang menyebutkan, bahwa pendidikan nasional berfungsi untuk mengembangkan kemampuan dan membentuk watak serta peradaban bangsa yang bermartabat dalam rangka mencerdaskan kehidupan bangsa. Seiring perkembangan zaman, pengimplementasian kurikulum di Indonesia terus mengalami penyempurnaan, dan untuk saat ini kurikulum yang digunakan Indonesia adalah kurikulum tingkat satuan pendidikan (KTSP) dan kurikulum 2013 (K13). Hery Widyastono (2015: 90) mengemukakan bahwa 
Kurikulum Tingkat Satuan Dasar adalah kurikulum yang disusun dan dilaksanakan dimasing-masing satuan pendidikan. KTSP terdiri dari tujuan pendidikan tingkat satuan pendidikan struktur dan muatan kurikulum tingkat satuan pendidikan, kalender pendidikan, dan silabus. Lebih lanjut menurut Hery Widyastono (2015: 119) mengenai Kurikulum 2013, bahwa kurikulum 2013 menekankan pengembangan kompetensi pengetahuan, keterampilan dan sikap peserta didik yang ketiganya dilakukan secara seimbang.

Implementasi kurikulum 2013 di SD/MI menggunakan pendekatan tematik integratif. Seperti yang ditegaskan oleh Mawardi (2014: 109) bahwa pembelajaran tematik integratife adalah pembelajaran yang memadukan beberapa muatan pelajaran dalam satu kali tatap muka dan dikemas dalam sebuah tema sebagai pemersatu kegiatan pembelajaran. Sedangkan dalam proses pembelajarannya Mawardi (2014: 114) juga menegaskan bahwa pendekatan saintifik atau pendekatan ilmiahlah yang digunakan dalam Kurikulum 2013 SD/MI. Dalam Kurikulum 2013 revisi menegaskan matematika menjadi salah satu mata pembelajaran yang berdiri sendiri. Terdapat berbagai alasan yang menyebabkan matematika tidak tergabung dalam pembelajaran tematik, salah satunya tidak semua pembahasan dalam matematik dapat dikaitkan dengan pembelajaran lain. Selain itu cakupan materi muatan pelajaran matematika tidak seluas ketika muatan pelajaran matematika disendirikan, hal tersebut mengakibatkan peserta didik tidak mendapatkan konsep matematika secara lebih matang dan mendalam.

Walaupun matematika menjadi salah satu muatan pembelajaran yang berdiri sendiri dalam Kurikulum 2013, hal ini tidak menjadi penghambat bagi guru untuk membuat pembelajaran matematika menjadi lebih menyenangkan, menantang dan bermakna. Dalam hal ini guru diharapkan dapat memilih model pembelajaran yang bervariasi dan efektif sehingga dengan penggunaan model pembelajaran yang efektif diharapkan dapat meningkatkan hasil belajar siswa. Pemilihan model pembelajaran menjadi sesuatu hal yang tidak mudah bagi guru, karena jika guru salah menerapkan model pembelajaran maka hal tersebut dapat menjadi suatu penghambat bagi keberhasilan proses belajar mengajar. Oleh sebab itu sebelum memutuskan menggunakan suatu model pembelajaran, guru hendaknya memperhatikan materi ajar serta karakteristik siswa. Mulyasa (2014: 143) menyampaikan model pembelajaran yang diutamakan dalam implementasi Kurikulum 2013 model pembelajaran inkuiri (inquiry based learning), diskovery (discovery learning), model pembelajaran berbasis proyek (project based learning), model pembelajaran berbasis permasalahan (problem based learning). Mengingat bahwa dalam Kurikulum 2013 langkah-langkah pembelajaran yang digunakan menggunakan pendekatan saintifik atau ilmiah yang sering disebut dengan $6 \mathrm{M}$ (mengamati, menanya, mengumpulkan informasi, mengasosiasi dan mengkomunikasi). Sehingga model pembelajaran dengan pendekatan ilmiah atau saintifik sangat disarankan.

Dalam pembelajaran matematika model pembelajaran yang cocok digunakan agar selama pembelajaran siswa dapat membangun pengetahuan yang baru berdasarkan penemuan atau penyelidika yang didapatkan adalah dengan menggunakan model discovery learning. Selain itu agar pembelajaran matematika tidak membosankan juga diperlukan terobosan model pembelajaran yang menantang rasa keingintahuan siswa untuk memecahkan suatu persoalan, yaitu dengan mengunakan model problem based learning. Oleh karena itu salah satu altenatif solusi model pembelajaran yang dapat digunakan dalam pembelajaran matematika agar dapat meningkatkan kualitas pembelajaran diantaranya melalui model discovery learning dan problem based learning.

Menurut. Kemendikbud (2016: 59), discovery learning adalah suatu proses pembelajaran dimana melibatkan siswa secara aktif untuk mengoorganisasikan sendiri materi pelajaran dengan menekankan pada penemuan suatu konsep atau prinsip yang sebelumnya belum diketahui siswa. Dalam hal ini siswa dilatih untuk membangun pengetahuannya sendiri berdasarkan pengalaman yang didapatkan, oleh karena itu diharapkan siswa mendapatkan sesuatu yang bermakna. Sedangkan Menurut Barrow seperti dikutip oleh Huda (2014: 271) mendefinisikan problem based learning sebagai pembelajaran yang diperoleh melalui proses yang menuju pemahaman akan resolusi suatu masalah.

Beberapa penelitian terdahulu berhasil membuktikan bahwa terdapat perbedaan hasil belajar menggunakan model pembelajaran discovery learning dan problem based learning (PBL). Hanif Maaarif dan Wahyudi (2015: 97) melakukan penelitian tentang eksperimentasi Problem Based learning dan CIRC dalam penyelesaian soal cerita matematika siswa kelas 5 SD. Dilakukannya penelitian ini bertujuan untuk mengetahui apakah penggunaan model Problem Based Learning lebih baik pada CIRC dalam kemampuan menyelesikan soal cerita matematika siswa kelas 5 SDN I Sedayu kecamatan Sapuran Kabupaten Wonosobo semester II. Hasil analisis menunjukkan $t_{\text {hitung }}=2,067$, dengan taraf signifikansi $\alpha=5 \%$ diperoleh $t_{\text {tabel }}=1,6698$. Hal tersebut dapat diartikan bahwa $t_{\text {hitung }}>t_{\text {tabel }}$ yang berarti $\mathrm{H}_{0}$ ditolak. Berdasarkan hasil olah data yang telah dilakukan, maka peneliti menyimpulkan bahwa penggunaan model pembelajaran Problem Based Learning lebih baik dari pada model CIRL dalam 
kemampuan menyelesaikan soal cerita matematika kelas 5 SD Negeri 1 Sedayu.

Namun hasil penelitian yang dilakukan Hanif Maaarif dan Wahyudi, bertolak belakang dengan temuan Mawardi \& Mariati (2016: 127), yang melakukan penelitian tentang komparasi model pembelajaran Discovery Learning dan Problem Solving ditinjau dari hasil belajar IPA pada siswa kelas 3 sd di Gugus Diponegoro. Penelitian Mawardi \& Mariati bertujuan untuk mengetahui perbedaan keefektifan pembelajaran menggunakan model pembelajaran Discovery Learning dan Problem Solving pada siswa kelas 3 SDN Bener 02 dan SDN Bener 01. Hasil penelitian yang dilakukan menunjukkan bahwa hasil uji $t$ skor postes menunjukkan t hitung 3,417 dan t tabel 2,201 dengan signifikasi 0,039. Karena nilai signifikasi $<0,05$ dan $t$ hitung $<\mathrm{t}$ tabel maka $\mathrm{H}_{0}$ ditolak, $\mathrm{H}_{\mathrm{a}}$ diterima. Maka dapat disimpulkan bahwa hasil belajar IPA kelas $3 \mathrm{di}$ Gugus Diponegoro Tengaran dengan menggunakan model Discovery Learning lebih tinggi dibanding model Problem Solving.

Hasil penelitian relevan terdahulu menunjukkan bahwa penggunaan model pembelajaran discovery learning dan problem based learning (PBL) dapat mempengaruhi hasil belajar. Namun disisi lain muncul keragu-raguan terhadap model pembelajaran yang lebih unggul yang dapat digunakan dalam pembelajaran matematika. Maka dari itu perlu dikaji lebih lanjut mengenai model pembelajaran discovery learning dan problem based learning (PBL).

Berdasarkan uraian latar belakang diatas, maka permasalahan dalam penelitian ini adalah apakah terdapat perbedaan secara signifikan pada hasil belajar matematika kelas 4 SD menggunakan model discovery learning dan problem based learning. Tujuan yang ingin dicapai pada penelitian ini yaitu untuk mengetahui ada tidaknya perbedaan secara signifikan hasil belajar matematika kelas4 SD menggunakan model discovery learning dan problem based learning. sehingga akan diketahui model mana yang lebih efektif digunakan dalam pembelajaran.

\section{B. KAJIAN PUSTAKA}

\section{Hakikat Matematika di SD}

Menurut Hamzah (2008: 129), menyatakan bahwa matematika adalah suatu bidang ilmu yang dapat digunakan dalam memecahkan berbagai persoalan, sebagai alat pikir, berkomunikasi, dimana didalam matematika terdapat berbagai unsur seperti, logika dan intusis, analisis dan kontruksi, generalitas dan individualitas, dan memiliki berbagai cabang diantaranya aritmatika, aljabar, geometri, dan analisis. Selanjutnya pengertian matematika secara praktis disampaikan oleh Sri Giarti (2014: 15) yang menyatakan bahwa matematika merupakan suatu pelajaran yang tersusun secara beraturan, logis, berjenjang dari yang paling mudah hingga ke yang paling rumit.

Berdasarkan paparan pendapat ahli di atas dapat disimpulkan bahwa matematika adalah salah satu mata pelajaran di SD yang tersusun secara beraturan, logis, dan berjenjang dimana dapat digunakan untuk memecahkan masalah atau persoalan yang memiliki berbagai cabang dan memiliki fungsi praktis dan teoritis. Dengan belajar matematika peserta didik diharapkan dapat menyelesaikan permasalahan dalam kehidupan sehari-hari yang berkaitan dengan matematika baik yang ditemui dalam lingkungan sekolah maupun masyarakat.

\section{Langkah Pembelajaran Matematika Sekolah Dasar}

Menurut Suhandi Astuti (2017: 49) dalam pembelajaran guru memiliki peran yang sangat penting. Output berupa siswa yang unggul bukanlah sesuatu yang mustahil jika guru bekerja secara professional. Apalagi dalam pembelajaran matematika tingkat SD langkah-langkah pembelajaran yang ditempuh guru harus benarbenar jelas, dengan demikian siswa tidak merasa bingung dengan apa yang disampaikan guru. Terlebih dalam penyampaian pembelajaran tingkat SD akan lebih baik jika saat pengajarannya mengunakan benda konkrit, sehingga konsep yang diterima siswa dapat tertanam.

Heruman (2010: 2), menyatakan bahwa konsepkonsep pada kurikulum matematika SD dibagi ke dalam 3 kelompok besar, yaitu penanaman konsep dasar, pemahaman konsep dan pembinaan keterampilan. Untuk mencapai tahap keterampilan, guru harus mencapai langkah-langkah secara benar, yang disesuaikan dengan kemampuan dan lingkungan peserta didik, mengingat karakter setiap peserta didik berbeda. Penyajian pembelajaran yang ditekankan pada konsep-konsep matematika menurut Heruman (2010: 2) antara lain: 1) Penanaman Konsep Dasar. Tahap penanaman konsep dasar merupakan pembelajaran suatu konsep baru matematika yang diajarkan kepada peserta didik untuk pertama kalinya. Pembelajaran penanaman konsep dasar juga merupakan jembatan bagi guru untuk menghubungkan kemampuan kognitif siswa yang konkret dengan konsep baru yang abstrak. Pendukung dalam pembelajaran penanaman konsep dasar matematika ini salah satunya dengan penggunaan media atau alat peraga, karena dengan guru mengunakan media atau alat peraga, pola pikir siswa dapat terbentuk secara perlahan dan sehingga memudahkan siswa untuk mengingat konsep baru yang diajarkan oleh guru. 2) Pemahaman Konsep. Pemahaman konsep merupakan lanjutan dari penanaman konsep dasar matematika. Tujuan dari pemahaman konsep yaitu agar peserta didik lebih memahami konsep matematika. Pemahaman konsep 
ini memiliki dua pengertian. Pertama, pemahaman konsep merupakan lanjutan dari penanaman konsep matematika dalam satu pertemuan. Kedua, pemahaman konsep merupakan pembelajaran pemahaman konsep yang dilakukan pada pertemuan yang berbeda, namun masih berupa lanjutan dari penanaman konsep. 3) Pembinaan Keterampilan . Pembinaan keterampilan merupakan pembelajaran yang ditempuh setelah guru menyampaikan penanaman konsep dan pemahaman konsep. Tujuan dari pembinaan keterampilan ini yaitu agar peseta didik dapat menerapkan konsep-konsep matematika dalam kehidupan sehari-hari. Sehingga pembelajaran matematika yang dipelajari siswa dapat diaplikasikan dalam dunia nyata.

\section{Kompetensi Inti dan Kompetensi Dasar Matematika Kelas VI SD}

Matematika merupakan salah satu muatan pelajaran yang diajarkan di sekolah dasar (SD). Pelajaran matematika yang diajarkan pada tingkat SD memiliki suatu kompetensi yang harus dicapai oleh peserta didik. Pencapaian kompetensi yang harus dicapai peserta didik dalam kurikulum 2013 disebut dengan KI dan KD. Kompetensi inti kelas IV diantaranya: KI1 Menerima, menjalankan, dan menghargai ajaran agama yang dianutnya; KI2 menunjukkan perilaku jujur, didiplin, tanggung jawab, santun, peduli, dan percaya diri dalam berinteraksi dengan keluarga, teman, guru dan tetangga; KI3 Memahami pengetahuan faktual dengan cara mengamati [mendengar, melihat, membaca] dan menanya berdasarkan rasa ingin tahu tentang dirinya, makhluk ciptaan Tuhan dan kegiatannya, dan bendabenda yang dijumpainya dirumah, sekolah dan tempat bermain; KI4 Menyajikan pengetahuan faktual dalam bahasa yang jelas dan logis dan sistematis, dalam karya yang estetis dalam gerakan yang mencerminkan anak sehat, dan dalam tindakan yang mencerminkan perilaku anak beriman dan berakhlak mulia.

Selanjutnya kompetensi dasar yang akan dipakai dalam penelitian ini dapat dilihat pada tabel $1 \mathrm{di}$ bawah ini.

TABEL 1

KOMPETENSI DASAR 3.8 DAN 4.8 MATEMATIKA KELAS 4 SEMESTER II

\begin{aligned} & \hline Kompetensi Dasar (KD) Matematika Kelas 4 \multicolumn{2}{c}{ Semester II } \\ & \hline 3.8 Menganalisis segi banyak \\ & beraturan dan segibanyak tidak \\ & beraturan. \\ & 4.8 $\begin{array}{l}\text { Mengidentifikasi segi banyak } \\ \text { beraturan dan segi banyak tidak } \\ \text { beraturan. }\end{array} \\ &$\hline\end{aligned}

Materi yang diambil untuk dijadikan bahan pembelajaran dalam penelitian ini yaitu materi pada kurikulum 2013 matematika kelas 4 pada bab bangun segi banyak. Materi tersebut akan diajarkan kepada peserta didik secara mendalam dengan menggunakan model pembelajaran yang berbeda. Model pembelajaran yang akan digunakan dalam pembelajaran matematika kelas 4 materi bangusn segi banyak yaitu model problem based learning dan discovery learning.

\section{Model Discovery Learning dan Problem Based learning}

Menurut Kemendikbud (2016: 59), discovery learning adalah suatu proses pembelajaran dimana melibatkan siswa secara aktif untuk mengoorganisasikan sendiri materi pelajaran dengan menekankan pada penemuan suatu konsep atau prinsip yang sebelumnya belum diketahui siswa. Sehingga dalam hal ini siswa belajar berdasarkan pengalaman yang telah dilakukan melalui percobaan. Mulyasa (2014: 144) menyampaikan beberapa langkah yang harus ditempuh guru dalam menerapkan model discovery learning diantaranya: 1$)$ stimulus; 2) identifikasi masalah; 3) pengumpulan data; 4) pengolahan data; 5) verifikasi dan 6) Generalisasi.

Kelebihan model discovery learning menurut Kemendikbud (2016: 62) diantaranya; 1) Membantu peserta didik dalam memperbaiki dan meningkatkan keterampilan dan proses-proses kognitif pada peserta didik; 2) Karena model ini peserta didik melakukan sebuah penyelidikan untuk mencapai suatu keberhasilan, maka selama proses pembelajaran peserta didik akan merasa senang; 3) Selama proses kegiatan belajar mengajar situasi belajar menjadi lebih menarik dan menyenangkan. Selain kelebihan discovery learning diatas, Kemendikbud (2016: 63) menyatakan beberapa kelemahan model ini jika diterapkan dalam pembelajaran diantaranya: 1) Tujuan pembelajaan mengunakan model ini sulit untuk tercapai, ketika guru dan siswa sudah terbiasa mengajar dengan menggunakan cara - cara belajar lama; 2) Pembelajaran menggunakan model discovery learning tidak efisien untuk mengajar siswa dalam jumlah banyak; 3) Tidak memberikan kesempatan untuk berfikir tentang sesuatu yang akan ditemukan oleh siswa.

Model selanjutnya yang akan dibandingkan dengan model discovery learning adalah model problem based learning. Menurut Hamruni (2009: 148), pembelajaran berbasis masalah adalah model pembelajaran yang menggunakan masalah dunia nyata sebagai suatu konteks bagi peserta didik untuk belajar mengenai cara berfikir kritis, mengembangkan keterampilan dalam pemecahan masalah, serta memperoleh pengetahua dan konsep baru yang didapatkan oleh peserta didik dalam pembelajaran. Adapun sintaks pembeajaran menurut Suyanto dan Asep Jihad (2013: 155) diantaranya: 1) mengarahkan peserta didik pada masalah; 2) mengorganisasikan peserta didik untuk belajar; 3) Membimbing peserta didik untuk melakukan 
penyeliikan individu maupun kelompok; 4) Mengembangkan dan menyajikan hasil karya; 5) Menganalisis dan mengevaluasi proses pemecahan masalah. Kemudian Mawardi \& Mariati (2016: 132) menegaskan bahwa penerapan model problem based learning dalam pembelajaran menuntut siswa untuk menyelesaikan pemecahan masalah yang disajikan oleh guru dengan cara menggali informasi, kemudian dari informasi tersebut dianalisis dan dicari solusi daripermasalahan yang ada.

Terdapat kelebihan dan kekurangan model problem based learning. Kelebihan model problem based learning menurut Hamruni Hamruni (2009: 157) diantaranya; 1) Meningkatkan aktivitas pembelajaran peserta didik; 2) Menantang kemampuan peserta didik serta memberikan kepuasan untuk menemukan pengetahuan baru bagi peserta didik; 3) Membantu peserta didik mengenai bagaimana cara mentransfer pengetahuan yang dimiliki peserta didik untuk memahami masalah dalam kehidupan nyata; 4) Menjadikan pembelajaran lebih menyenangkan. Selain kelebihan tersebut, model problem based learning juga memiliki kelemahan seperti yang dikemukakan oleh Hamruni (2009: 157) beberapa kelemahan pada model pembelajran berbasis masalah diataranya: 1) Bagi peserta didik yang tidak memiliki minat atau tidak memiliki rasa percaya diri bahwa sesulit apapun masalah yang dipelajari itu dapat dipecahkan, maka peserta didik akan merasa enggan untuk mencoba; 2 ) Keberhasilan penerapan pembelajaran dengan menggunakan model pembelajaran berbasis masalah ini membutuhkan cukup waktu untuk persiapan; 3) Tanpa pemahaman mengapa peserta didik berusaha untuk memecahkan masalah yang sedang dipelajari, maka peserta didik tidak akan belajar apa yang mereka ingin pelajari.

Model pembelajaran yang dipilih oleh guru tentunya memiliki unsur-unsur yang membangun. Hal tersebut sejalan dengan Bruce Joyce, Marsha Weil, dan Emily Calhoun (2011: 104), bahwa setiap modelmodel pembelajaran memiliki unsur-unsur begitu juga dengan model discovery learning dan problem based learning. Unsur-unsur yang dimaksud berupa (1) sintagmatik; (2) prinsip reaksi; (3) sistem social; (4) daya dukung; (5) dampak intruksional dan dampak pengiring. Penjelasan kelima unsur tersebut diantaranya sebagai berikut: 1) Sintagmatik adalah langkah-langkah atau tahapan yang harus ditempuh oleh guru ketika menggunakan model pembelajaran yang telah dipilih; 2) Prinsip reaksi ini berkaitan dengan bagaimana peran guru dalam pelaksanaan pembelajaran; 3) Sistem sosial adalah hubungan guru dengan peserta didik yang terlihat pada saat proses kegiatan belajar mengajar berlangsung dengan menggunakan model pembelajaran implementasikan pada saat itu; 4) daya dukung adalah pendukung yang dibutuhkan atau diperlukan dalam pembelajaran; 5) Dampak intruksional adalah pencapaian hasil belajar peserta didik yang berkaitan langsung dengan materi pembelajaran, sedangkan dampak pengiring adalah hasil belajar lain yang diperoleh peserta didik sebagai akibat dari penggunaan model pembelajaran tertentu.

\section{Kajian Penelitian yang Relevan}

Penelitian yang dilakukan Rismaerista Rini \& Mawardi (2015: 103) meneliti tentang penggunaan model Problem Based Learning sebagai upaya peningkatan keterampilan proses saintifik dan hasil belajar siswa kelas 4 Tema Peduli Terhadap Lingkungan. Tujuan penelitian tindakan kelas ini adalah untuk mengetahui peningkatan keterampilan proses saintifik dan hasil belajar dengan menggunakan model Problem Based Learning pada siswa kelas 4 SDN Slungkep 02. Hasil analisis data menunjukkan bahwa terdapat perbedaan hasil dari siklus I dan siklus II. Hal ini dapat dibuktikan bahwa terdapat peningkatan keterampilan proses saitifik dan hasil belajar siswa kelas 4 pada Tema 4 Peduli Terhadap Lingkungan. Peneliti menyimpulkan bahwa penerapan model Problem Based Learning dapat meningkatkan keterampilan proses saintifik dan hasil belajar siswa kelas 4 SDN Slungkep 02.

Wahyudi \& Mia Christy Siswanti (2015: 23) melakukan penelitian tentang pengaruh model Discovery Learning dengan permainan ditinjau dari hasil belajar matematika siswa kelas 5. Tujuan dilakukannya penelitian ini untuk mengetahui apakah penerapan model Discovery Learning dengan permainan dapat meningkatkan hasil belajar matematikan siswa kelas 5 semseter II SD Kristen 3 Eben Haezer. Hasil analisis data menunjukkan ratarata kelas eksperimen 80,84 sedangkan kelas control 71,75. Hal tersebut juga didukung oleh nilai signifikan yaitu 0,000<0,05 yang berarti bahwa Ho ditilak dan Ha diterima. Simpulan yang diberikan peneliti adalah penerapan model Discovery Learning melalui permainan memiliki pengaruh terhadap hasil belajar siswa kelas 5 SD SD Kristen 03 Eben Haezer.

Hanif Maaarif dan Wahyudi (2015: 97) melakukan penelitian tentang eksperimentasi Problem Based learning dan CIRC dalam penyelesaian soal cerita matematika siswa kelas 5 SD. Dilakukannya penelitian ini bertujuan untuk mengetahui apakah penggunaan model Problem Based Learning lebih baik pada CIRC dalam kemampuan menyelesikan soal cerita matematika siswa kelas 5 SDN I Sedayu kecamatan Sapuran Kabupaten Wonosobo semester II. Hasil penelitian menunjukkan bahwa kelas eksperimen yang menggunakan model Problem Based Learning memiliki rata-rata 79,09 , sedangkan kelas eksperimen yang menggunakan model CIRL memiliki rata-rata 75,38. Hasil analisis menunjukkan $t_{\text {hitung }}=$ 2,067, dengan taraf signifikansi $\alpha=5 \%$ diperoleh $t_{\text {tabel }}=1,6698$. Hal tersebut dapat diartikan bahwa 
$t_{\text {hitung }}>\mathrm{t}_{\text {tabel }}$ yang berarti $\mathrm{H}_{0}$ ditolak. Berdasarkan hasil olah data yang telah dilakukan, maka peneliti menyimpulkan bahwa penggunaan model pembelajaran Problem Based Learning lebih baik dari pada model CIRL dalam kemampuan menyelesaikan soal cerita matematika kelas 5 SD Negeri 1 Sedayu.

M. Taufik \& Dasniati (2018: 49) meneliti tentang upaya meningkatan keterampilan proses siswa dengan menggunakan model pembelajaran discovery learning pada materi cahaya dan sifat-sifatnya. Hasil penelitian yang diperoleh menunjukkan bahwa melalui model discovery learning dalam pembelajaran terjadi peningkatan persentase rerata keterampilan proses siswa yaitu siklus I $60 \%$ di siklus II menjadi $88,6 \%$. Selanjutnya rata-rata aktifitas belajar guru pada siklus I sebesar $80 \%$ dan pada siklus II mengalami peningkatan menjadi $92 \%$, sedangkan kegiatan siswa pada siklus I sebesar $60 \%$ dan mengalami peningkatan pada siklus II menjadi $88,5 \%$. Maka dapat disimpulkan bahwa pembelajaran materi sifat-sifat cahaya menggunakan model discovery learning dapat meningkatkan keterampilan proses siswa.

Sri Sukaptiyah (2015: 114) melakukan penelitian tindakan kelas (PTK) tentang penerapan model Problem Based Learning untuk meningkatkan hasil belajar PKn siswa kelas VI SDN 1 Mongkrong. Penelitian ini bertujuan untuk mengetahui peningkatan hasil belajar PKn melalui penerapan model Problem Based Learning pada siswa kelas VI SD Negeri 1 Mongkrong Wonosgoro. Hasil penelitian menunjukkan bahwa melalui penerapan model Problem Based Learning dapat mempengaruhi prestasi siswa kelas VI. Hal ini dibuktikan dengan meningkatnya hasil belajar PKn siswa setelah penerapan model pembelajaran Problem Based Learning. Maka peneliti menyimpulkan bahwa hasil belajar siswa dapat meningakat setelah penerapan model Problem Based Learning.

Septiani Wahyu Tumurun, Diah Gusrayani dan Asep Kurnia Jayadinata (2016: 101) yang meneliti tentang pengaruh model pembelajaran discovery learning terhadap keterampilan berfikir kreatif siswa pada materi sifat-sifat cahaya. Tujuan penelitian eksperimen ini adalah untuk mengetahui apakah terjadi peningkatan keterampilan berfikir kreatif dengan menggunakan model discovery learning dan model konvensional. Berdasarkan hasil penelitian implementasi model discovery learning dan konvensional sama-sama dapat meningkatkan keterampilan berfikir kreatif. Namun didapatkan hasil bahwa pembelajaran dengan model discovery learning lebih dapat meningkatkan keterampilan berfikir kreatif secara signifikan. Hal tersebut dibuktikan dari hasil hasil perhitungan uji beda ratarata data gain pada kedua kelompok sampel memiliki nilai sig (1-tailed) sebesar 0,001.
Rumini \& Naniek Sulistya Wardani (2016: 19), melakukan penelitian tentang peningkatan hasil belajar Tema Berbagai Pekerjaan dengan menggunakan model Discovery Learning pada siswa kelas 4 SDN Kutoharjo 01. Hasil penelitian tindakan yang dilakukan tersebut menunjukkan terdapat peningkatan hasil belajar dari siklus 1 ke siklus 2 Tema Berbagai Pekerjaan pada siswa kelas IV dengan menggunakan model Discovery Learning. Hasil penelitian menunjukkan bahwa terdapat peningkatan hasil belajar dengan menggunakan model Discovery Learning pada Tema Berbagai Pekerjaan. Hal ini dibuktikan dari hasil analisis sebagai berikut: 1) Hasil belajar berdasarkan ketuntasan belajar dengan $\mathrm{KKM} \geq 80$ meningkat dari pra siklus ke siklus 1 dan siklus 2 yakni dari $0 \%$, 69,23\% dan 88,46\%; 2) Hasil belajar berdasarkan skor minimal dari pra siklus ke siklus 1 dan siklus 2 yakni dari 20: 53: 66; 3) Hasil belajar berdasarkan skor maksimal dari pra siklus ke siklus 1 dan siklus 2 yakni 45; 92; 100; 4) Hasil belajar berdasarkan skor rata-rata dari pra siklus ke siklus 1 dan siklus 2 yakni dari 37,1: 78,5: 88,0. Maka dari hasil diatas dapat disimpulkan bahwa penerapan model Discovery Learning dapat meningkatkan hasil belajar siswa Tema Berbagai Pekerjaan kelas 4 SDN Kutoharjo 01 dan penelitian ini dikatakan berhasil.

Mawardi \& Mariati (2016: 127), melakukan penelitian tentang komparasi model pembelajaran Discovery Learning dan Problem Solving ditinjau dari hasil belajar IPA pada siswa kelas 3 sd di Gugus Diponegoro. Tujuan penulis melakukan penelitian ini adalah untuk mengetahui perbedaan keefektifan pembelajaran menggunakan model pembelajaran Discovery Learning dan Problem Solving pada siswa kelas 3 SDN Bener 02 dan SDN Bener 01. Hasil penelitian yang dilakukan menunjukkan bahwa hasil uji $\mathrm{t}$ skor postes menunjukkan $\mathrm{t}$ hitung 3,417 dan $\mathrm{t}$ tabel 2,201 dengan signifikasi 0,039. Karena nilai signifikasi $<0,05$ dan $\mathrm{t}$ hitung $<\mathrm{t}$ tabel maka $\mathrm{H}_{0}$ ditolak, $\mathrm{H}_{\mathrm{a}}$ diterima. Maka dapat disimpulkan bahwa hasil belajar IPA kelas 3 di Gugus Diponegoro Tengaran dengan menggunakan model Discovery Learning lebih tinggi dibanding model Problem Solving.

Penelitian relevan selanjutnya dilakukan oleh Firosalia Kristin \& Dwi Rahayu (2016: 84) mengenai pengaruh penerapan model pembelajaran Discovery Learning terhadap hasil belajar IPS siswa kelas 4 SD". Tujuan dari penelitian ini adalah untuk mengetahui adakah pengaruh penggunaan penerapan model Discovery Learning terhadap hasil belajar IPS kelas 4 SD Koripan 01. Hasil penelitian menunjukkan bahwa penerapan model Discovery Learning memiliki pengaruh terhadap pembelajaran IPS. Hal ini dibuktikan dengan adanya peningkatan hasil belajar IPS siswa kelas 4 SDN Koripan 04 dengan menerapkan model Discovery Learning. Maka dapat 
disimpulkan bahwa penerapan model Discovery Learning dalam pembelajaran IPS dapat meningkatkan hasil belajar siswa kelas 4 SDN Koripan 04. Perbedaan penelitian diatas dengan penelitian yang akan dilakukan terletak pada jenis penelitian dan muatan pelajaran yang akan diterapkan model.

Adhini Virginia \& Wasitohadi (2016: 100) meneliti tentang efektivitas model Problem Based Learning berbantu media audio visual ditinjau dari hasil belajar ipa siswa kelas 5 SDN 1 gadu. Penelitian ini bertujuan untuk mengetahui perbedaan hasil belajar antara model Problem Based Learning berbantu media audio visual dengan model pembelajaran Think Pair Share berbantu media visual pada pembelajaran IPA siswa kelas 5 SDN 1 Gadu Sambong. Dalam penelitian ini kelompok eksperimen diterapkan model Problem Based Learning sedangkan kelompok control diterapkan model Think Pair Share. Hal ini dibuktikan bahwa perbedaan rata-rata kelas eksperimen > kelas control yaitu 87,0588>80,2000. Berdasarkan hasil analisis data maka peneliti menyimpulkan terdapat perbedaan tingkat evektivitas antara model Problem Based Learning berbentu media audio visual dengan model pembelajaran Think Pair Share berbantu media visual terhadap hasil belajar siswa kelas 5 SDN 1 Gadu Kecamatan Sambong.

I Dewa Gede Wianjana Putra, A.A. Gede Agung dan Desak Putu Parmiti (2017: 1) melakukan penelitian tentang pengarun model pembelajaran Discovery Learning berbasis lingkungan terhadap hasil belajar IPA pada siswa kelas V Gugus II Kecamatan Tampaksiring. Penelitian ini dilatarbelakangi oleh rendahnya hasil belajar IPA kelas 5 SD Gugus II Kecamatan Tampaksiring Kabupaten Gianyar. Tujuan penelitian ini adalah untuk mengetahui apakah terdapat pengaruh hasil belajar IPA yang signifikan dengan menerapkan model pembelajaran Discovery Learning. Hasil penelitian menunjukkan bahwa penerapan model Discovery Learning memiliki pengaruh terhadap pembelajaran IPA. Hal ini diperkuat dari hasil olah data yang menunjukkan bahwa nilai $t_{\text {hitung }}$ sebesar 9,86 dan $t_{\text {tab }}$ sebesar 2,00, artinya $t_{\text {hitung }}>t_{\text {tab. }}$. Berdasarkan hasil analisis yang telah dilakukan, peneliti menyimpulkan bahwa penerapan model pembelajaran Discovery Learning berbasis lingkungan memiliki pengaruh yang signifikan terhadap hasil belajar IPA siswa kelas V semester II tahun pelajaran 2016/2017 di SD Gugus II Kecamatan Tampaksiring.

Maria Patrisia Wau (2017: 239) melakukan penelitian tentang pengaruh model Problem Based Learning terhadap hasil belajar IPS pada siswa kelas IV SDI Bajawa. Tujuan dilakukannya penelitian ini adalah untuk mengetahui ada tidaknya pengaruh penggunaan model Problem Based Learning terhadap hasil belajar IPS siswa kelas IV SDI Bajawa. Hasil penelitian menunjukkan bahwa terdapat penerapan model Problem Based Learning berpengaruh tehadap hasil belajar IPS. Hal ini dibuktikan bahwa $\mathrm{H}_{\mathrm{o}}$ ditolak dan $\mathrm{H}_{1}$ diterima. Kemudian diperoleh rata-rata kelompok eskperimen lebih tinggi dibanding kelompok control yaitu $66,40>56,9$. Berdasarkan analisis data yeng telah dilakukan, penulis menyimpulkan bahwa penerapan model Problem Based Learning memiliki dampak yang signifikan dibandingkan model konvensional terhadap hasil belajar IPS siswa kelas IV SDI.

Aries Setiarini (2016: 203) melakukan penelitian tentang cara meningkatkan motivasi dan hasil belajar peserta didik dengan mengoptimalkan penerapan pendekatan saintifik strategi discovery learning dan metode diskusi. Penelitian tindakan kelas ini bertujuan untuk mengetahui efektifitas penerapan pendekatan saintifik strategi discovery learning dan metode diskusi dalam peningkatan motivasi serta hasil belajar. Hasil penelitian ini menunjukkan bahwa hasil akhir tindakan siklus II mengenai hasil observasi guru sebear 4,64 sedangkan hasil observasi peserta didik mencapai skor rata-rata 4,21. Sedangkan rata-rata hasil belajar sebagai dampak peningkatan hasil belajar adalah 89,38. Hal terssebut berarti indikator keberhasilan lebih dari sama dengan 4,0 dan hasi belajar lebih dari sama dengan 75. Sehingga dapat disimpulkan bahwa penelitian ini dikatakan berhasil dikarenakan indikator keberhasilan telah terbukti.

Penelitian selanjutnaya dilakukan Rani Nopia, Julia dan Atep Sujana (2016: 641) yang meneliti tentang pengaruh model Problem Based Learning terhadap keterampilan berfikir kritis siswa sekolah dasar. Tujuan dilakukannya penelitian ini adalah untuk mengetahui ada tidaknya pengaruh penerapan model pembelajaran Problem Based Learning terhadap peningkatan kemampuan berfikir kritis pada materi daur air. Sampel penelitian ini adalah siswa kelas V SDN Pasanggrahan II (kelompok eksperimen) dan siswa kelas V SDN Pasanggrahan III. Hasil penelitian menunjukkan bahwa penerapan model Problem Based Learning dan model konvensional sama-sama dapat meningkatkan keterampilan berfikir kritis, namun secara signifikan penerapan model Problem Based Learning lebih baik untuk meningkatkan keterampilan berfikir kritis, hasil penelitian juga diperkuat dengan adanya respon positif siswa terhadap pembelajaran dengan model Problem Based Learning.

Rizal Abdurrizak, Asep Kurnia jayadinata \& Iisrok Atun (2016: 817) melakukan penelitian tentang pengaruh model Problem Based Learning terhadap kemampuan berfikir kreatif siswa. Penelitian eksperimen ini bertujuan untuk mengetahui apakah penerapan model Problem Based Learning dapat meningkatkan kemampuan berfikir kreatif siswa. 
Sampel dari penelitianini adalah siswa kelas IV SDN Paseh 2 dan SDN Ledok Berdasarkan hasil analisis data menunjukkan bahwa penerapan Model Problem Based Learning memberikan pengaruh. Hal ini dibuktikan dengan: 1) meningkatnya kemampuan berfikir kreatif siswa, 2) meningkatnya hasil belajar siswa, 3) kemampuan berfikir kreatif siswa dengan menggunakan model PBL lebih baik dibanding menggunakan model konvensional, 4) dalam meningkatkan kemampuan berfikir kreatif siswa terdapat factor pendukung dan penghambat. Dari hasil diatas peneliti menyimpulkan secara singkat bahwa penggunaan model Problem Based Learning dapat meningkatkan kemapuan berfikir kreatif siswa walaupun terdapat faktor penghambat dan pendukung dalam peningkatan kemampuan berfikir kreatif tersebut.

\section{METODE PENELITIAN}

Penelitian ini menggunakan jenis penelitian eksperimen. Sugiyono (2014: 72), metode penelitian eksperimen dapat diartikan sebagai metode peelitian yang digunakan untuk mencari pengaruh dari perlakuan tertentu dibawah kondisi buatan. Desain penelitian eksperimen yang digunakan adalah desain eksperimen semu atau Quasi Experimental Design dengan bentuk Nonequivalent Control Group Design. Dalam desain ini terdapat 2 kelompok yaitu kelompok eksperimen dan kontrol. Sebelum kelompok eksperimen dan kontrol diberi perlakuan/treatment, kedua kelompok diberi pretest terlebih dahulu setelah itu baru kemudian kedua kelompok diberi perlakuan/treatment. Kelompok eksperimen dalam penelitian ini diberi perlakuan dengan model problem based learning, sedangkan kelompok kontrol diberi perlakuan dengan model discovery learning.

Sampel penelitian ini adalah siswa kelas 4 SDN 1 Kaligentong (SD inti), siswa kelas 4 SDN 2 Urutsewu dan siswa kelas 4 SDN 3 Urutsewu di Gugus Slamet Riyadi Ampel-Boyolali dengan jumlah sampel secara keseluruhan 68 anak. Instrument pengumpulan data dalam penelitian ini menggunakan soal tes dan lembar observasi. Soal tes dalam penelitian ini digunakan untuk mengukur hasil belajar siswa baik sebelum (pretest) ataupun sesudah (posttest) dikenakan treatmen.

Selanjutnya untuk mengetahui aktifitas guru dan siswa apakah pembelajaran yang laksanakan sesuai sintaks maka digunakan instrument observasi yang berupa lembar observasi aktifitas guru dan siswa. Teknik analisis yang digunakan berupa uji prasyarat yang terdiri dari uji normalitas dan uji homogenitas serta uji $\mathrm{t}$ atau uji beda dengan independent sample $t$ test. Menurut Priyatno (2010: 71) Uji normalitas digunakan untuk mengetahui apakah data yang diuji terdistribusi normal atau tidak. Setelah uji normalitas terpenuhi maka pengujian selanjutnya yaitu uji homogenitas. Uji homogenitas digunakan untuk mengetahui apakah sampel berasal dari populasi yang memiliki varian sama atau homogen. Tahap terakhir yang akan dilakukan yaitu analisis uji t atau uji beda dengan independent sample t test. Analisis uji t atau uji beda ini dilakukan untuk mengetahui untuk mengetahui ada tidak adanya perbedaan hasil belajar posttest kelompok eksperimen yang diberi perlakuan dengan model problem based leraning dan kelompok kontrol yang diberi perlakuan dengan model discovery learning.

\section{HASIL DAN PEMBAHASAN}

Penelitian ini dilakukan di 3 SD Gugus Slamet Riyadi diantaranya Kaligentong (SD inti), SDN 2 Urutsewu, SDN 3 Urutsewu pada siswa kelas 4 materi bangun segi banyak semester II tahun pelajaran $2017 / 2018$. Pertemuan pada kelas eksperimen dan kontrol masing-masing sebanyak 3 kali dengan alokasi waktu setiap pertemuan 2 x 35 menit (70 menit). Peran guru kelas selama pelaksanaan penelitian adalah sebagai pengamat, sedangkan pemberian perlakuan dilakukan oleh peneliti sendiri. Berikut akan diuraikan hasil penelitian dan pembahasan yang telah dilakukan oleh peneliti.

\section{Deskripsi Data Kelompok Eksperimen}

Treatmet/perlakuan yang diberikan pada kelompok eksperimen berupa penerapan model problem based learning. Berikut disajikan hasil statistik deskriptif kelompok eksperimen dalam bentuk tabel hasil pretest dan posttes yang didalamnya memuat rata-rata nilai (mean), skor tertinggi (max), skor terendah (min), standar deviasi. Pengolahan data analisis statistik deskriptif ini menggunakan program SPSS for windows version 22.

TABEL 2

STATISTIK DESKRIPTIF SKOR PRETEST DAN POSTTEST KELOMPOK EKSPERIMEN

\begin{tabular}{lccccc}
\hline & N & Min & $\begin{array}{c}\text { Ma } \\
\mathbf{x}\end{array}$ & Mean & $\begin{array}{c}\text { Std. Devia- } \\
\text { tion }\end{array}$ \\
\hline Pre_PBL & 34 & 24 & 72 & 49.18 & 12.241 \\
\hline Pos_PBL & 34 & 44 & 92 & 73.76 & 11.906 \\
\hline $\begin{array}{l}\text { Valid N } \\
\text { listwis } \\
\text { e) }\end{array}$ & 34 & & & & \\
\hline
\end{tabular}

Berdasarkan Tabel 2 di atas dapat diketahui bahwa sebelum mendapatkan perlakuan menggunakan model problem based learning nilai rata-rata pretest kelompok eksperimen sebesar 49,18 dengan standar deviasi 12,241. Sedangkan setelah kelompok ekperimen diberi perlakuan dengan menerapkan model problem based learning dalam pembelajaran nilai rata-rata posttest meningkat menjadi 73,76 dengan standar deviasu 11,906. Hal lain yang tampak adalah skor tertinggi yang dicapai sebelum pemberian perlakuan adalah 72 dan skor terendah adalah 24 . 
Namun setelah diberi perlakuan skor tertinggi yang berhasil dicapai adalah 92 dan skor terendahnya 44. Adapun jumlah peserta didik yang mengikuti pretest dan posttest sebanyak 34 anak.

\section{Deskripsi Data Kelompok Kontrol}

Treatmet/perlakuan yang diberikan pada kelompok kontrol berupa penerapan model discovery learning. Berikut disajikan hasil statistik deskriptif kelompok kontrol dalam bentuk tabel hasil pretest dan posttes yang didalamnya memuat rata-rata nilai (mean), skor tertinggi (max), skor terendah (min), standar deviasi. Pengolahan data analisis statistik deskriptif ini menggunakan program SPSS for windows version 22.

TABEL 3

STATISTIK DESKRIPTIF NILAI PRETEST DAN POSTTEST KELOMPOK KONTROL

\begin{tabular}{lccccc}
\hline & N & Min & Max & Mean & $\begin{array}{c}\text { Std. } \\
\text { Devia- } \\
\text { tion }\end{array}$ \\
\hline Pre_DL & 34 & 24 & 72 & 50.12 & 12.848 \\
\hline Pos_DL & 34 & 52 & 96 & 80.12 & 11.031 \\
\hline $\begin{array}{l}\text { Valid N } \\
\text { (listwis } \\
\text { e) }\end{array}$ & 34 & & & & \\
\hline
\end{tabular}

Berdasarkan Tabel 3 di atas dapat dilihat bahwa sebelum proses pembelajaran mendapatkan perlakuan menggunakan model discovery learning nilai rata-rata pretest kelompok kontrol sebesar 50,12 dengan standar deviasi 12,848 . Sedangkan setelah kelompok kontrol diberi perlakuan menggunakan model discovery learning nilai rata-rata posttest kelompok kontrol meningkat menjadi 80.12 dengan standar deviasi 11.031. Tabel di atas juga menunjukkan bahwa skor tertinggi sebelum diberi perlakuan adalah 72 dan skor terendah 24. Namun setelah kelompok kontrol diberi perlakuan berupa penerapan model discovery learning skor tertinggi yang berhasil diperoleh sebesar 96 dan skor terendah 52 . Jumlah siswa yang mengikuti pretest dan posttest kelompok kontrol ini adalah 34 anak.

\section{Deskripsi Kompaasi Hasil Pengukuran Hasil Belajar Kelompok Eksperimen dan kelompok Kontrol}

Berdasarkan uraian hasil analisis statistik deskriptif di atas terlihat bahwa hasil belajar siswa kelompok kontrol dengan perlakuan model discovery learning lebih tinggi dibanding dengan kelompok eksperimen dengan perlakuan problem based learning. Hasil pengukuran dari kelompok eksperimen dan kontrol berdasarkan nilai pretest dan posttest pelajaran matematika kelas 4 Gugus Slamet Riyadi selanjutnya dipaparkan dalam bentuk deskripsi komparasi. Rincian deskripsi komparatif ini disajikan dalam bentuk tabel dan gambar. Berikut merupakan hasil perbedaan pada kelompok eksperimen dan kontrol yang dapat dilihat pada tablel 4 .

TABEL 4

TABEL KOMPARASI HASIL PENGUKURAN KELOMPOK EKSPERIMEN DAN KONTROL SD GUGUS SLAMET RIYADI

\begin{tabular}{|c|c|c|c|}
\hline \multirow{2}{*}{$\begin{array}{c}\text { Tahap } \\
\text { Pengukuran }\end{array}$} & \multicolumn{2}{|c|}{ Rerata skor (mean) } & \multirow{2}{*}{$\begin{array}{l}\text { Keterangan } \\
\text { selisih }\end{array}$} \\
\hline & Eksperimen & Kontrol & \\
\hline $\begin{array}{l}\text { Awal } \\
\text { (pretetst) }\end{array}$ & 49,18 & 50,12 & 0,94 \\
\hline $\begin{array}{l}\text { Akhir } \\
\text { (posttets) }\end{array}$ & 73.76 & 80.12 & 6.36 \\
\hline
\end{tabular}

Berdasarkan tabel 4 di atas maka dapat dilihat nilai rata-rata kelas eksperimen pada tahap awal (pretest) adalah 49,18 dan pada tahap akhir (posttest) nilai rata-rata kelompok eksperimen mengalami kenaikan 73.76. Sedangkan pada kelompok kontrol diperoleh nilai rata-rata 50,12 pada tahap awal (pretest) dan pada tahap akhir (posttest) nilai rata-rata kelompok kontrol menjadi 80.12 pada tahap akhir. Selanjutnya untuk selisih nilai rata-rata tahap awal kelompok eksperimen dan kontrol sebesar 0,94 sedangkan pada tahap akhir sebesar 6.36. Secara ringkas deskripsi komparasi hasil pengukuran tersebut dapat dilihat pada gambar 1 sebagai berikut.

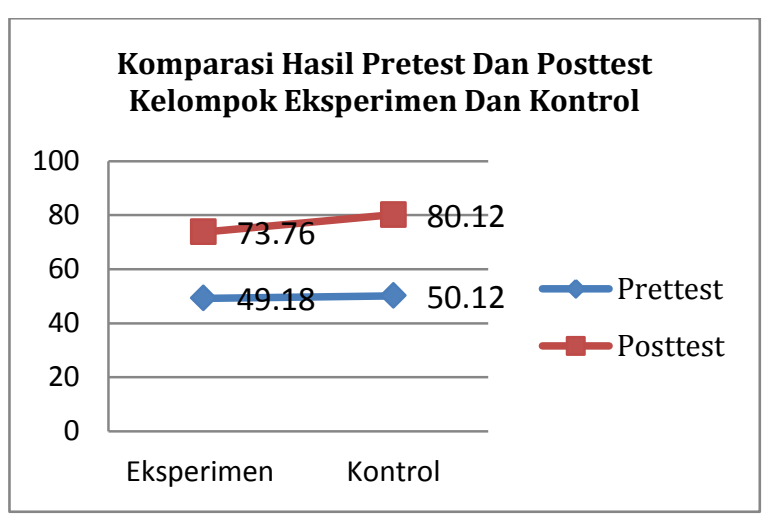

Gambar 1. Deskripsi Komparasi Skor Pretest dan Posttest Kelompok Eksperimen dan Kontrol SD Gugus Slamet Riyadi

\section{Analisis Uji t atau Uji Beda Rata-rata Hasil Belajar}

Setelah uji prasyarat telah terpenuhi, maka pengujian yang dilakukan selanjutnya adalah uji $t$ atau uji beda rata-rata hasil belajar. Uji $t$ dilakukan pada nilai posttest kelompok eksperimen yang diberi perlakuan dengan menggunakan model problem based learning dan nilai posttses kelompok kontrol yang diberi perlakuan dengan menggunakan model discovery learning. analisis uji t atau uji beda ini dilakukan dengan bantuan program SPSS for windows versi 22. Berikut dipaparkan hasil uji $\mathrm{t}$ atau uji beda menggunakan uji $\mathrm{t}$ Independent $T$ Test yang dapat dilihat pada tabel 5. (Terlampir) 
Berdasarkan tabel 5 terlampir tampak bahwa $t_{\text {hitung }}$ sebesar $-2,282$. Hasil analisis uji t atau uji beda menggunakan asusmi $t$-test for equality of means dengan Sig (2-tailed) sebesar 0,026 sehinga didapat (1-tailed) sebesar 0,013. Dikarenakan nilai signifikan (2-tailed) 0,026 < 0,05 (0,026 lebih kecil dari 0,05), maka dapat diartikan bahwa Ho ditolak dan Ha diterima.

\section{Pembahasan}

Penelitian eksperimen ini dilakukan di SD Gugus Slamet Riyadi dengan mengambil sampel penelitian diantaranya SDN 1 Kaligentong yang berstatus sebagai SD inti, SDN 2 Urutsewu yang berstatus sebagai SD imbas jauh dan SDN 3 Urutsewu yang berstatus sebagai SD imbas dekat. Tujuan dilakukannya penelitian ini adalah untuk menguji ada tidaknya perbedaan secara signifikan pada hasil belajar matematika kelas 4 SD dalam pembelajaran menggunakan model discovery learning dan problem based learning Gugus Slamet Riyadi semester II tahun pelajaran 2017/2018. Pemberian treatment model problem based learning diimplementasikan pada kelompok eksperimen sedangkan pada kelompok kontrol diberikan treatmen berupa model discovery learning.

Berdasakan analisis statistik deskriptif hasil belajar matematika kelas 4 materi bangun segi banyak, diperoleh nilai rata-rata pretest kelompok eksperimen dan kontrol adalah 49,18 dan 50,12. Sedangkan nilai rata-rata posttest kelompok eksperimen dan kelompok kontrol adalah 73.76 dan 80.12. Dari data tersebut menunjukkan bahwa setelah diberikan perlakuan berupa penerapan model problem based learning dan discovery learning, baik nilai rata-rata posttest kedua kelompok sama-sama memberikan peningkatan.

Berdasarkan analisis uji $t$ atau beda rata-rata nilai posttest kelompok eksperimen dan kontrol menunjukkan hasil signifikasi (2-tailed) sebesar 0,026. Dikarenakan nilai signifikan (2-tailed) sebesar 0,026 lebih kecil dari $\alpha=0,05(0,026<\alpha$ $=0,05$ ), maka dapat diartikan bahwa terdapat perbedaan hasil belajar pada kelompok eksperimen dan kontrol. Sehingga didapatkan hipotesis bahwa Ho ditolak dan Ha diterima, yang dapat diartikan bahwa hasil belajar dengan menggunakan model pembelajaran discovery learning lebih tinggi secara signifikan dibandingkan model pembelajaran problem based learning pada pelajaran matematika kelas IV SD Gugus Slamet Riyadi. Menurut Mulyasa (2014: 144) model pembelajaran discovery learning merupakan model pembelajaran dimana peserta didik dapat menemukan sesuatu yang bermakna dalam pembelajaran. Sintaks pembelajaran yang harus ditempuh dalam menggunakan model discovery learning menurut diantaranya: 1) pemberian stimulus, 2) mengidentifikasi masalah, 3) pengumpulan data, 4) pengolahan data, 5) pembuktian, dan 6) penarikan kesimpulan. Penggunaan model discovery learning yang dilakukan pada kelas kontrol membawa pengaruh positif bagi siswa dalam pembelajaran. Hal ini ditunjukkan dari aktifitas siswa selama proses pembelajaran dengan menggunakan model discovery learning diantaranya; 1) siswa yang diterapkan model discovery learning mengikuti pembelajaran dengan antusias serta aktif, apalagi pada waktu siswa melakukan percobaan dengan alat dan bahan yang telah guru siapkan, semua siswa berlomba-lomba untuk menyelesaikan percobaan pada lembar kerja kelompok yang guru berikan, 2) penangkapan materi dalam penggunaan mode discovery learnig lebih mudah diterima oleh siswa, hal tersebut dikarenakan siswa belajar dari pengalaman sendiri serta melakukan percobaan yang membuat hal ini memperkuat pemahaman siswa terhadap materi yang dipelajari, 3) dalam setiap langkah-langah pembelajaran menggunakan model discovery learning, siswa dapat mengikuti setiap langkah-langkah dengan baik, hal ini membuat pelaksanaan pembelajaran dengan discovery learning berjalan dengan lancar, 4) hampir seluruh siswa mengerjakan soal posttest yang diberikan guru dengan baik. Beberapa pengaruh positif tersebut yang terlihat pada proses pembelajaran dengan menggunakan model discovery learning, sehingga dalam penerapannya model discovery learning lebih efektif digunakan, terbukti dari uji t yang telah dilakukan oleh peneliti.

Hasil penelitian yang telah dilakukan peneliti sejalan dengan penelitian terdahulu, sehingga mendukung hasil temuan peneliti. Penelitian terdahulu yang mendukung temuan peneliti tersebut antara lain, Wahyudi \& Mia Christy Siswanti (2015: 23) yang meneliti mengenai pengaruh model Discovery Learning dengan permainan ditinjau dari hasil belajar matematika siswa kelas 5. Kelas eksperimen dalam penelitian diterapkan model discovery learning sedangkan kelas kontrol diterapkan model konvensional. Berdasarkan analisis data yang telah dilakukan diperoleh hasil bahwa rata-rata kelas eksperimen 80,84 sedangkan kelas kontrol 71,75. Bukti selanjutnya didapatkan dari perhitungan uji $\mathrm{t}$ yang memperoleh nilai signifikasi yaitu $0,00<$ 0,05 yang berarti bahwa Ho ditolak dan $\mathrm{Ha}$ diterima. Sehingga dalam hal ini penggunaan model discovery learning dengan permainan dapat meningkatkan hasil belajar siswa kelas 5 Semester II SD Kristen 3 Eben Haezer. 
Temuan Septiani Wahyu Tumurun, Diah Gusrayani dan Asep Kurnia Jayadinata (2016: 101) mengenai pengaruh model pembelajaran discovery learning terhadap keterampilan berfikir kreatif siswa pada materi sifat-sifat cahaya juga mendapatkan hasil yang senada dengan temuan yang diperoleh peneliti. Dalam penelitiannya Septiani Wahyu Tumurun, Diah Gusrayani dan Asep telah membuktikan bahwa penggunaan model discovery learning dapat menigkatkan keterampilan berfikir kritis secara signifikan dibandingkan menggunakan model konvensional. Hal tersebut dibuktikan dari hasil hasil perhitungan uji beda rata-rata data gain pada kedua kelompok sampel memiliki nilai sig (1tailed) sebesar 0,001.

Penelitian selanjutnya yang mendukung temuan dari peneliti adalah penelitian yang dilakukan Rumini \& Naniek Sulistya Wardani (2016: 19), namun jenis penelitian ini berbeda dengan penelitian yang dilakukan oleh peneliti. Walaupun jenis penelitian yang dilakukan Rumini \& Naniek Sulistya Wardani berbeda, hasil penelitian yang telah dilakukan sama-sama menunjukkan bahwa diterapkannya model discovery learning dapat meningkatkan hasil belajar siswa. Hal ini dibuktikan berdasarkan hasil analisis data dalam PTK yang menunjukkan bahwa berdasarkan skor rata-rata dari pra siklus ke siklus 1 dan siklus 2 yakni dari 37,1: 78,5: 88,0 .

Penelitian eksperimen yang dilakukan Mawardi \& Mariati (2016: 127) juga memperoleh hasil yang senada dengan penelitian yang telah peneliti lakukan. Penelitian yang dilakukan Mawardi \& Mariati mengenai komparasi model pembelajaran Discovery Learning dan Problem Solving ditinjau dari hasil belajar IPA pada siswa kelas 3 sd di Gugus Diponegoro memiliki tujuan untuk mengetahui lebih efektif mana model discovery leraning dengan model problem solving pada siswa kelas 3 SDN Bener 02 dan SDN Bener 01 . Hasil penelitian ini menunjukkan bahwa Ho tolak dan Ha diterima. Hal tersebut berarti bahwa penggunaan model discovery learning lebih efektif digunakan dibandingkan model problem solving dalam pembelajaran IPA siswa kelas 3 Gugus Diponegoro.

Penelitian tindakan kelas yang dilakukan oleh Firosalia Kristin \& Dwi Rahayu (2016: 84) mengenai pengaruh penerapan model pembelajaran Discovery Learning terhadap hasil belajar IPS siswa kelas 4 SD juga mendukung hasil dari penelitian yang telah peneliti lakukan. Hasil yang diperoleh Firosalia Kristin \& Dwi Rahayu dalam penelitiannya yaitu penerapan model discovery learning dapat meningkatkan hasil belajar IPS kelas 4 SD Koripan 01.
Selain beberapa penelitian di atas, penelitian tindakan kelas yang dilakukan Aries Setiarini (2016: 203) mengenai cara meningkatkan motivasi dan hasil belajar peserta didik dengan mengoptimalkan penerapan pendekatan saintifik strategi discovery learning dan metode diskusi juga memperoleh hasil bahwa penerapan model discovery learning dapat meningkatkan motivasi dan hasil belajar peserta didik. Walaupun jenis penelitian yang dilakukan Aries Setiarini berbeda dengan jenis penelitian yang dilakukan peneliti, namun penelitian Aries mampu membuktikan bahwa discovery learning dapat meningkatkan motivasi dan hasil belajar peserta didik.

Hasil penelitian tindakan kelas yang dilakukan M. Taufik \& Dasniati (2018: 49) juga mendukung hasil penelitian yang telah dilakukan peneliti. Penelitian yang dilakukan oleh M. Taufik \& Dasniati berhasil membuktikan bahwa penggunaan model discovery learning dapat meningkatkan keterampilan proses siswa dalam materi sifat-sifat cahaya. Hal tersebut dibuktikan dari terjadinya peningkatan persentase rata-rata pada siklus II.

I Dewa Gede Wianjana Putra, A.A. Gede Agung dan Desak Putu Parmiti (2017: 1) juga mendapatkan hasil yang serupa dengan hasil penelitian yang telah peneliti lakukan. Dengan latar belakang rendahnya hasil belajar IPA kelas 5 SD Gugus II Kecamatan Tampaksiring Kabupaten Gianyar. Hasil penelitian menunjukkan bahwa signifikasi t hitung $>\mathrm{t}$ tabel. Hal tersebut berarti bahwa penerapan model pembelajaran discovery learning berbasis lingkungan memiliki pengaruh yang signifikan terhadap hasil belajar IPA siswa kelas V semester II tahun pelajaran 2016/2017 SD gugus II kecamatan Tampaksiring.

Selain memperkuat hasil penelitian yang telah dilakukan oleh Wahyudi \& Mia Christy Siswanti, Septiani Wahyu Tumurun, Diah Gusrayani dan Asep Kurnia Jayadinata, Rumini \& Naniek Sulistya Wardani, Mawardi \& Mariati, Firosalia Kristin \& Dwi Rahayu, Aries Setiarini, M. Taufik \& Dasniati, I Dewa Gede Wianjana Putra, A.A. Gede Agung dan Desak Putu Parmiti. Peneliti menemukan hasil penelitian yang bertolak belakang dengan temuannya.

Rismaerista Rini \& Mawardi (2015: 103). Penelitian tindakan kelas yang dilakukan Rismaerista Rini \& Mawardi menunjukkan bahwa dengan menggunakan model problem based learning dapat meningkatkan proses saintifik dan hasil belajar siswa kelas 4 tema 4 peduli terhadap lingkungan. Perbedaan hasil juga ditunjukkan oleh Hanif Maaarif dan Wahyudi dalam penelitiannya mengenai eksperimentasi model problem based learning dan CIRL dalam kemampuan menyelesaikan soal cerita 
matematika kelas 5 SDN 1 Sedayu. Hasil penelitian yang didapat menunjukkan bahwa penerapan model problem based learning lebih baik dibanding model CIRL.

Senada dengan hasil penelitian yang dilakukan oleh Hanif Maaarif dan Wahyudi. Penelitian tindakan kelas yang dilakukan oleh Sri Sukaptiyah (2015: 114) juga tidak sejalan dengan hasil penelitian yang telah peneliti lakukan. Perbedaan tersebut terlihat dari hasil penelitian tindakan kelas yang menunjukkan bahwa hasil belajar siswa dapat meningkat selelah diterapkannya model problem based learning pelajaran PKn.

Hasil penelitian eksperimen yang dilakukan oleh Adhini Virginia \& Wasitohadi (2016: 100) mengenai perbedaan tingkat efektivitas antara model problem based learning berbantu media audio visual dengan model pembelajaran thik pair and share berbantu media visual juga tidak senada dengan hasil penelitian yang dilakukan oleh peneliti. Diperoleh hasil bahwa rata-rata kelas eksperimen dengan model problem based learning > dengan rata-rata kelas kontrol dengan model think pair and share yaitu 87,0588 > 80,2000 . Sehingga hal tersebut menunjukkan bahwa terdapat perbedaan efektifikas penggunaan model problem based learning dan think pair and share terhadap hasil belajar siswa kelas 5 SDN 1 Gadu.

Hasil penelitian yang dilakukan oleh Maria Patrisia Wau (2017: 239) juga bertolak belakang dengan hasil penelitian yang dilakukan oleh peneliti. Penelitian Maria Patrisia Wau ini menunjukkan bahwa penerapan model problem based learning dalam pembelajaran memberikan dampak yang signifikan dibandingkan model konvensional. Hal tersebut dibuktikan berdasarkan hasil uji hipotesis yang telah dilakukan yang menyatakan bahwa $\mathrm{H}_{\mathrm{o}}$ ditolak dan $\mathrm{H}_{1}$

Rani Nopia, Julia dan Atep Sujana (2016: 641) yang melakukan penelitian eksperimen mengenai pengaruh model Problem Based Learning terhadap keterampilan berfikir kritis siswa sekolah dasar juga mendapatkan hasil yang berbeda dari penelitian yang telah peneliti lakukan. Penelitian yang dilakukan Rani Nopia, Julia dan Atep Sujana menunjukkan bahwa kemampuan berfikir kritis secara signifikan dapat meningkat setelah penerapan model problem based learning. Terakhir, hasil penelitian terdahulu yang bertolak belakang dengan hasil penelitian yang telah peneliti lakukan yaitu penelitian yang dilakukan Rizal Abdurrizak, Asep Kurnia Jayadinata \& Iisrok Atun (2016: 817). Hasil penelitian eksperimen tersebut menunjukkan bahwa penggunaan model problem based learning dapat meningkatkan kemampuan berfikir kreatif siswa.

\section{E. SIMPULAN DAN SARAN}

\section{Simpulan}

Berdasarkan analisis data dan hasil penelitian yang telah dibahas pada bab sebelumnya, maka dapat disimpulkan bahwa hasil belajar dengan menggunakan model pembelajaran discovery learning lebih tinggi secara signifikan dibandingkan model pembelajaran problem based learning pada pelajaran matematika kelas IV SD Gugus Slamet Riyadi. Simpulan tersebut didasarkan pada uji $t$ yang dilakukan dengan teknik Independent Sample T-Test pada hasil belajar posttest pembelajaran dengan model problem based learning (kelompok eksperimen) dan discovery learning (kelompok kontrol). Hasil uji t menunjukkan bahwa sig. (2-tailed) sebesar 0,026. Oleh karena nilai signifikasi 0,026 <0,05, maka Ho ditolak dan Ha diterima yang berarti bahwa hasil belajar dengan menggunaka model discovery learning lebih tinggi secara signifikan dibanding model pembelajaran problem based learning pada pelajaran matematika kelas IV SD Gugus Slamet Riyadi Semester II Tahun Pelajaran 2017/2018

\section{Saran}

Berdasarkan hasil penelitian yang telah dilakukan maka terdapat beberapa saran yang diberikan peneliti kepada:

a. Guru

Oleh karena hasil belajar dengan menggunakan model discovery learning lebih tinggi secara signifikan dibandingkan dengan model problem based learning, maka guru diharapkan dapat mengimplementasikan model discovery learning yang lebih efektif digunakan dalam pembelajaran untuk meningkatkan hasil belajar siswa dalam pembelajaran matematika dengan disesuaikan materi yang akan diajarkan.

b. Kepala Sekolah

Kepala sekolah dapat mensosialisasikan maupun mengadakan pelatihan terkait model discovery learning kepada guru kelas ataupun kepala sekolah lain. Dengan demikian model discovery learning ini dapat digunakan guru dalam mengembangkan proses pembelajaran yang kreatif, inovatif dan menyenangkan.

c. Peneliti Selanjutnya

Adanya penelitian dapat digunakan sebagai referensi untuk mengembangkan penelitian selanjutnya, namun dengan memperhatikan keterbatasan yang terdapat dalam penelitian ini. Sehingga diharapkan untuk kedepannya penelitian yang dilakukan dapat lebih baik. 


\section{UCAPAN TERIMA KASIH}

Penulis mengucapkan terimakasi kepada semua pihak yang telah membantu proses penelitian. Terutama kepada SD Gugus Slamet Riyadi (SDN 1 Kaligentong, SDN 2 Urutsewu, SDN 3 Urutsewu) yang telah memberikan kesempatan kepada penulis untuk melakukan penelitian di tempat tersebut dan seluruh pihak yang tidak mungkin penulis ucapkan satu persatu.

\section{REFERENSI}

[1] Astuti, S. (2017). Supervisi akademik Untuk Meningkatkan Kompetensi Guru Di SD laboratorium UKSW. Scholaria: Jurnal Pendidkan dan Kebudayaan, 7(1), 49-59.

[2] Giarti, S. (2014). Peningkatan Keterampilan Proses Pemecahan Masalah Dan Hasil Belajar Matematika Menggunakan Model PBL Terinttegrasi Penilaian autentik Pada Siswa Kelas VI SDN 2 Bengle Wonosegoro. Scholaria: Jurnal Pendidkan dan Kebudayaan, 4(3), 13-27.

[3] Hamruni. (2009). Strategi dan Model-Model Pembelajaran Aktif Menyenangkan. Yogyakarta: Fakultas Tarbiyah UIN Sunan Kalijaga.

[4] Heruman. 2014. Model Pembelajaran Matematika. Bandung: PT Remaja Rosdakarya.

[5] Kemendikbud. (2016). Panduan Teknis Pembelajaran dan Penilaian di Sekolah Dasar .

[6] Kristin, F., \& Rahayu, D. (2016). Pegaruh Penerapan Model Pembelajaran Discovery Learning Terhadap Hasil belajar IPS Pada Siswa Kelas 4 SD. Scholaria: Jurnal Pendidkan dan Kebudayaan, 6(1), 84-92.

[7] Maarif, h., \& Wahyudi. (2015). Eksperimentasi Problem Based Learning Dan CIRC Dalam Menyelesaikan Soal Cerita Matematika Siswa Kelas 5 SD. Scholaria: Jurnal Pendidikan dan Kebudayaan, 5(2), 97-115.

[8] Mawardi. (2014). Pemberlakuan Kurikulum SD/MI Tahun 2013 Dan ImplikasinyaTerhadap Upaya memperbaiki Proses Pembelajaran Melalui PTK. Scholaria: Jurnal Pendidikan dan Kebudayaan, 4(3), 107-121.

[9] Mawardi, \& Mariati. (2016). Komparasi Model pembelajaran Discovery Learning Dan problem Solving Ditinjau Dari Hasil Belajar IPA Pada Siswa kelas 3 SD Di Gugus Diponegoro- Tengaran. Scholaria: Jurnal Pendidikan dan Kebudayaan, 6(1), 127-142

[10] Nopia, R., Julia, \& Sujana, A. (2016). Pengaruh Model Problem Based Learning Terhadap Keterampilan Berfikir Kritis Siswa Sekolah dasar Pada Materi Daur Air. Jurnal Pena Ilmiah, 1(1), 641-650.

[11] Priyatno, Dwi. 2010. Paham Analisa Statistik Data Dengan SPSS. Yogyakarta: Mediakom.

[12] Putra, I. D., Agung, A. G., \& Parmiti, D. (2017). Pengaruh Model Pembelajaran Discovery Learning Berbasis Lingkungan Terhadap Hasil Belajar IPA Pada Siswa Kelas V Semester Genap Tahun Pelajaran 2016/2017 Di SD Gugus II Kecamatan Tampaksiring. e-Journal Mimbar PGSD, 5(2), 1-10
[13] Rini, R., \& Mawardi. (2015). Peningkatan Keterampilan Proses saintifik dan Hasil Belajar Siswa Kelas 4 SDN Slungkep 02 Tema Peduliterhadap Makhluk Hidup Menggunakan Model Problem Based Learning. Scholaria: Jurnal Pendidikan dan Kebudayaan, 5(1), 103-113.

[14] Rumini, \& Sulistya, N. W. (2016). Upaya Peningkatan Hasil Belajar Tema Berbagai Pekerjaan Melalu Model Discovery Learning Siswa Kelas 4 SDN Kutoharjo 01 Pati Kabupaten Pati Semester 1 Tahun Ajaran 2014-2015. Scholaria: Jurnal Pendidikan dan Kebudayaan, Vol. 6 No. 1, 19-40.

[15] Setiarini, A. (2016). Meningkatkan Motivasi dan Hasil Belajar Peserta Didik dengan Mengoptimalkan Penerapan Pendekatan Saintifik Strategi Discovery Learning dan Metode Diskusi di SDN Model Matara . Jurnal Kependidikan, 15(3), 202-210.

[16] Sugiyono. (2014). Metode Penelitian Pendidikan Pendekatan Kuantitatif, Kualitatif, dan R\&D. Bandung: Alfabeta.

[17] Sukaptiyah, S. (2015). Peningkatan Hasil Belajar PKn Melalui Model Problem Based Learning Pada Siswa Kelas VI SD Negeri 1 Mongkrong Wonosegoro. J Scholaria: Jurnal Pendidikan dan Kebudayaan, 5(1), 114-121.

[18] Suyanto, \& Jihad, A. (2013). Menjadi Guru Profesional. Jakarta: Erlangga.

[19] Taufiq, M., \& Dasniati. (2018). Upaya Meningkatkan Keterampilan Proses Siswa dengan Menggunakan Model Pembelajaran Discovery Learning Pada Materi Cahaya dan Sifat-sifatnya. Jurnal Pendidikan Almuslimin, (6), 1, 49-53.

Tumurun, S. W., Gusrayani, D., \& Jayadinata, A. K. (2016). Pengaruh Model Pembelajaran Discovery Learning Terhadap Keterampilan Berfikir Kreatif Pada Siswa Materi Sifat-sifat Cahaya. Jurnal Pena Ilmiah, (1), 1, 101-110.

[20] Virgiana, A., \& Wasitohadi. (2016). Efektivitas Model Problem Based Learning Berbantu Media Audio Visual Ditinjau Dari Hasil Belajar IPA Siswa Kelas 5 SDN 1 gadu Sambong-Blora Semester 2 Tahun 2014/2015. Scholaria: Jurnal Pendidikan dan Kebudayaan, 6(2), 100-118.

[21] Wahyudi, \& Siswanti, M. C. (2015). Pengaruh Pendekatan Saintifik Melalui Model Discovery Learning Dengan Permainan Terhadap Hasil Belajar Matematika Siswa Kelas 5 SD. Scholaria: Jurnal Pendidikan dan Kebudayaan, 5(3), 23-36.

[22]Wau, M. P. (2017). Pengaruh Model Problem Based Learning Terhadap Hasil Belajar IPS pada Siswa Kelas IV SDI Bajawa Kecamatan Bajawa Kabupaten Ngada. Journal of Education Technology, 1(4), 239-245.

[23] Widyastono, H. (2015). Pengembangan Kurikulum Di Era Otonomi Daerah dari Kurikulum 2004, 2006 ke Kurikulum 2013. Jakarta: Bumi Aksara. 
TABEL 5

HASIL UJI INDEPENDENT SAMPLE T-TEST POSTTEST

KELOMPOK EKSPERIMEN DAN KONTROL

Independent Samples Test

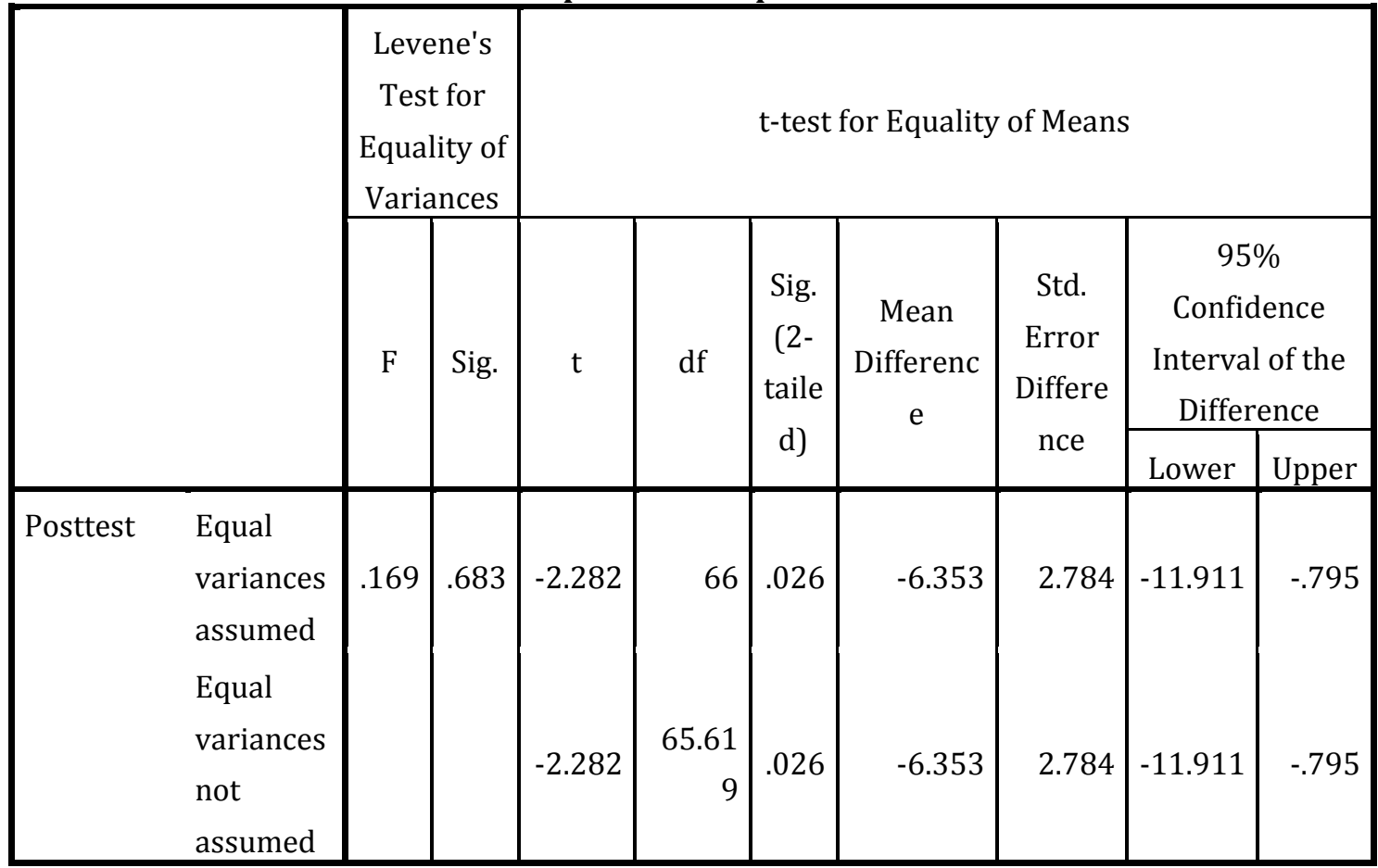

Sumber: Data penelitian diolah dengan menggunakan SPSS versi 22 